\title{
SHEEPSKIN EFFECTS IN THE RETURNS TO HIGHER EDUCATION: NEW EVIDENCE FOR MALAYSIA
}

\author{
Norhanishah Mohamad Yunus \\ School of Distance Education, Universiti Sains Malaysia, \\ 11800 USM Pulau Pinang, Malaysia \\ E-mail: norhanishah@usm.my
}

Published online: 30 June 2017

To cite this article: Yunus, N.M. (2017). Sheepskin effects in the returns to higher education: New evidence for Malaysia. Asian Academy of Management Journal, 22(1), 151-182. https://doi.org/10.21315/aamj2017.22.1.7

To link to this article: https://doi.org/10.21315/aamj2017.22.1.7

\begin{abstract}
The aim of this study is to distinguish between the returns to education from mere years of schooling as a reflection of their productive-enhancing contribution (human capital) and the returns to education from certificates of qualification which serve as signals of individual's ability (sheepskin effects). In order to do so, the present study relies on data from Household Income Survey (HIS) 2002-2012. Even though the overall result found the sheepskin effects serve as a higher signal of productivity compared to years of schooling in enabling individuals to seek higher returns in the labour market, the sheepskin effects from both diploma and university degrees are different between two phases: 2002-2007 and 2007-2012. The over-education and under-skilled situation respectively occur among degree and diploma holders in the Malaysian business services sector might be evidence that the sheepskin effects for both credentials are limited to provide higher signal to employers compared to university dropout between 2002 and 2007. However, the patterns of sheepskin effects between 2007 and 2012 are significantly different from 2002 and 2007. The present study discovered that the sheepskin effects brought some substantial earnings than years of schooling with the largest individual's sheepskin effects - associated with the degree and diploma qualifications. Due to the increasingly importance of academic certificate in determining the labour market earning, this study suggests the higher learning institutes to further strengthen their collaboration with employers and representatives of skilled workers from relevant industries in the quality assurance process and accreditation. This is to ensure that the skills needed in the labour market are incorporated in the university curriculum as these are effective in increasing graduate's employability.
\end{abstract}

Keywords: returns to education, sheepskin effects, years of schooling, earnings, certificates of qualification, over-education

(C) Asian Academy of Management and Penerbit Universiti Sains Malaysia, 2017. This work is licensed under the terms of the Creative Commons Attribution (CC BY) (http://creativecommons. org/licenses/by/4.0/). 


\section{INTRODUCTION}

In spite of many evidences show that the education generally pays off, but there are still a number of unresolved and debated research questions concerning the relationship between education and earnings (Ferrer \& Riddell, 2002; Mora, 2003; Bauer, Dross, \& Haisken-Denew, 2005; Teixeira, 2007). One of these concerns with the interpretation of the reasons of more educated individuals, leading to higher earnings and more prestigious occupations when there are less available educated candidates to be employed. According to the human capital theory, education or training increases the productivity of workers by imparting useful knowledge and skills, thereby raising workers' future income by increasing their lifetime earnings (Becker, 1962; Schultz, 1961).

One prediction of the human capital theory notion is that education raises the productivity of an individual and higher wages exist. This assumption prevails largely due to its success to describe the relationship between schooling and earnings in the earnings function (Psacharopoulos \& Patrinos, 2004). On the contrary, the screening theory claims that the positive education-earnings relationship is brought mainly by employers who prefer to hire applicants with degrees and diplomas in better-paying job market. Hence, sheepskin effects that describe certificates as signals of higher productivity) can be used to evaluate the screening theory of education $^{1}$ (Bauer et al., 2005).

An investigation on the role of sheepskin effects in the individual's earning provides additional insights to the human capital theory-screening hypothesis debate (Bauer et al., 2005; Pons \& Blanco, 2005). Indeed, the existence and magnitude of sheepskin effects is the central of the a debate over 'human capital' versus 'signalling/screening' theories of the role of education in the economy (Ferrer \& Riddell, 2002; Riddell, 2008). Sheepskin effects also have research and policy interest because they provide estimates of the value of completing educational programs (e.g.: Ferrer \& Riddell, 2002; Bauer et al., 2005; Jepsen, Troske, \& Coomes, 2014; Xu \& Trimble, 2016). In the case of Malaysia, sheepskin effects are important because not only they notify policymakers about the effectiveness of different types of certificates of qualification, but they provide information about the practices of Malaysia's labour market and the condition of labour's demandsupply (Yunus \& Said, 2016). This is because the study about the role of sheepskin effects in the returns to education in Malaysia has not been conducted in Malaysia including in business services sector (Yunus, 2014).

Hence, this study aims at enhancing the literature in two ways. First, the present study discusses in details about the contrast between human capital versus 
signalling/screening theories to explain the relationship between education and earnings at sectoral level. Only a few studies paid attention to estimate the return to education in economic sectors. To the author's best knowledge, only studies by Bauer et al. (2005), Bañuls and Ramón Rodríguez (2005), and Thrane (2010) estimated the returns to education in economic sectors by shedding light on the issues whether the returns to education from mere years of education as a reflection of individuals' productive-enhancing contribution (human capital) or the returns to schooling from certificates as signals of individuals' ability (sheepskin effects' argument). However, the aforementioned study was conducted in developed countries. In fact, in the context of developing countries, the sheepskin effects in the returns to education need to be explored because the issue of human capital versus signalling has a huge importance for developing countries in contemplating investment in education as a growth strategy (Hanushek, 2013).

Second, with the Household Income Survey (HIS) data, this study aims to provide the analysis on the trend of average private returns to education at different levels of the highest certificates of qualification achieved in the business services sector during 2002-2012. While doing this, over time, a particular attention is paid to the use of comparable data sets, as well as the application of similar methodology to these data sets. This approach enables an assessment of the changes in the private returns to education by different levels of certificates of qualification as the issue of unwillingness among employers in the business services sector to pay salary based on workers' level of highest certificate qualification in the business services sector has become the current interest (Yunus, 2014; EPU \& World Bank, 2007).

In the case where degree and diploma effects exist, there arises the question whether there is a really proper sheepskin effects. ${ }^{2}$ This is particularly important as much of the apparent fall in the returns to education, particularly for new graduates, is concentrated specifically on graduates who fail to get graduate-level jobs and they tend to be over- or under-education ${ }^{3}$ (EPU \& World Bank, 2012; Yunus, 2017; Yunus \& Hamid, 2016). Starting in the 2000s, a period of rapid economic growth and long-term relationship between employers and employees became the norms in most Malaysian firms as there are ongoing concerns among employers about the skills provided by Malaysian education system. The graduates are lacking in both technical know-how and generic skills. In this case, the employers in Malaysia's business services sector already possess considerable information on the innate productivity of their employees at the time of hiring, which in turn implies a secondary role of university degree and diploma as a screening device (EPU \& World Bank, 2012). In fact, a special recruitment system had been implemented to recruit productive workers as wages are closely linked to certificates of qualification held by employees and additional years of schooling. Both certificates and years of education serve as signals of productivity. 


\section{LITERATURE REVIEW}

The positive relationship between formal education, productivity, and labour market earnings is one of the most frequently studied empirical findings in economics literature. Studies which investigate the rates of return for education are likely to differ in many regards. However, on average, studies found that individuals with higher education levels are often associated with higher labour market earnings (Beblavy, Teteryatnikova, \& Thum, 2013; Liu, Belfield, \& Trimble, 2015; Yunus \& Said, 2016; Yunus \& Hamid, 2016). Similarly, it is found that education generally shares a positive association with the probability of employment, where more educated candidates are not only more prone to procure employment than the less educated candidates, but also more likely to procure better employment (Cellini \& Chaudhary, 2014; Yunus \& Said, 2016).

The human capital theory and the sorting model are two popular ventured theories that explain the nature of causality between education and productivity, thereby providing a theoretical justification for the correlation between education and earnings. These theories hypothesize the specific mechanism through which education affects earnings. According to human capital theory, education influences earnings directly by raising the productivity of workers through the augmentation of their innate capacity and the installation of relevant skills (Becker, 1962; Schultz, 1961). The first empirical application of human capital theory was carried out by Mincer, showing that earnings vary linearly with years of schooling and quadratic ally with work experience (Mincer \& Polachek, 1974).

However, earnings accelerate in response to education and by reasons of any effects on the productivity level. It is also based simply on the view of the fact that education acts as a signal of productivity. Employers, in believing that education is correlated with productivity, screen workers for their education level and pay higher wages to those having a higher education level. Meanwhile, the sorting model is simply an extension of the human capital model. This model explains about the effects of education on earnings and it has both human capital component and sorting dimension (Spence, 1973; Weiss, 1995).

The sorting model reveals that the primary function of education is to give indication to employers in the labour market, and the innate productivity is related to the characteristics of workers. There are two models under the sorting model, namely 'signalling hypothesis' and 'screening hypothesis' (Spence, 1973). The primary difference between these two theories is its game-theoretical nature. The signalling hypothesis explains that workers are informed about their own productivity through different levels of education, aimed at signalling their innate 
abilities to prospective employers. On the contrary, under the screening hypothesis, employers are uninformed about employee productivity. They demand minimum level of education from applicants or simply look at their given level of educational attainment screening prospective employees and infer their innate abilities.

In the context of education, signalling and screening share a special kind of dichotomy. Screening is effective if individuals' educational attainment is able to give a signal that convinces employers about their natural abilities because employers use educational attainment signal as a screening tool in the selection of candidates for work. In another attempt to prove signalling theory, economists point to 'sheepskin effects' as evidence that education acts as a signal. Using both spline and step functions, Hungerford and Solon (1987) confirmed the existence of sheepskin effects in the returns to education. They identified significantly larger returns to diploma years than to other years of education. They argued that workers are rewarded not only for the productive-enhancing contribution of schooling, but also for obtaining the diploma that comes with completing a particular level of schooling.

Hungerford and Solon (1987) also noted that the marginal returns to education are exceptionally large in diploma years (in year 12 and year 16 in the US). They found that discontinuities in returns were observed for certificated years. In this case, certificates of completion have economic returns which are independent against years of education. This finding confirms the predictions of signalling theory. Later, Heywood (1994), and Belman and Heywood (1997) consistently supported the findings of Hungerford and Solon (1987).

However, Jaeger and Page (1996) were of limited value support for the sorting model as they lacked direct measures of degree attainment. By contrast, Jaeger and Page (1996) own analyses of the US data included measures of both (accumulated) years of education and degree attainment. Their results generally revealed that the receipt of a degree brought about some substantial earnings benefits the total number of years of completed schooling. As such, this finding could be interpreted as a more valid sheepskin effect. Jaeger and Page (1996) findings also indicated that the sheepskin effects were about twice as large as the ones reported by Hungerford and Solon (1987).

Using varieties of Jaeger and Page (1996) approach, Park (1999) investigated the relationship between the years of schooling and level of certificate achieved. Using information from a special Current Population Survey (CPS) to estimate the sheepskin effects and by applying the quantile regression technique, the results revealed that the years of schooling and the level of certificate achieved that interact 
with additional years of schooling increase according to level of qualification. The returns for workers with a bachelor's degree was $21 \%$ compared to workers with an associate degree and high-school diploma, which were at $11 \%$ and $9 \%$, respectively.

Mora and Muro (2008) found that there are additional salaries of approximately an increment of $26 \%$ for university degree holders and $14 \%$ for individuals who hold a secondary degree in Colombia. In a similar pattern, Gibson (2000) documented sheepskin effects too. More precisely, he calculated the annual earnings and benefits of a postgraduate education compared to non-schooling, exceeded $50 \%$ for males, controlling for years of education. Ferrer and Riddell (2002) found that the returns for bachelor's degree was approximately $25 \%$ for both genders compared with a high school diploma in Canada. The analogous returning to a professional degree exceeded by $35 \%$. This study revealed that the importance of credentials increases with educational attainment, accounting for $30 \%$ of the return to 16 years of schooling but more than half of returns above 16 years. The results indicated that both years of schooling and degree's certificate of completion influence earnings.

In regard to the evidences of sheepskin effects in the of return to education in economic sector, Thrane (2010) was the first to study on the Norwegian tourism industry. The study found that the earnings of returns to educational degrees is the net of returns to the accumulated years of schooling. The results statistically and economically showed significant sheepskin effects, with the returns to educational degrees clearly exceed the returns to years of schooling for both male and female employees. Alba-Ramírez and San Segundo (1995) indicated that secondary education is better compensated in the private sector. A university degree receives a greater rate of return in the public sector in Spain. The returns to university education is higher among women than men regardless of the class of worker and the sector of employment.

Bañuls and Ramón Rodríguez (2005) explored the returns to education for workers in Spanish tourism sector. The results indicated that (a) the Spanish tourism employees value their level of education as somewhat less than other service sectors; (b) the size of the firm plays an important role in wage determinants; and (c) the pattern of lifelong earnings is different for workers with higher and lower levels of education. Pons and Blanco (2005) applied the Hungerford and Solon (1987) method to examine the relationship between education and earnings in public-private sector in the Spanish labour market. After controlling for selection into private and public employment, they found little evidence of sheepskin effects in the private sector. Higher flexibility in the private sector allows employers to use certificates as signals of greater productivity. In the public sector, this 
study discovered that educational requirement is a stringent rule of selection for applicants than that of a signal mechanism. Bauer et al. (2005) examined the role of sheepskin effects in Japan and found about $50 \%$ of the total returns to schooling. In this case, education is seen as an important signal for workers in small firms. Also, the size of these effects is similar to comparable estimates for the USA. This result clearly shows that the Japanese labour market is starkly different from that in the North America. Bauer et al. (2005) further found that the effects of estimated degree decrease with firm tenure, particularly for small firms. These results could be explained by a particular recruitment system of large firms in Japan, which make university diploma as a screening device.

In the literature, to date, there are increasing number of studies which do not support the sheepskin prediction and reveal a non-linear relationship between education and earnings. Psacharopoulos and Layard (1979) concluded that the rates of return to dropouts are as high as to those who complete a course. This refutes the sheepskin version of the screening hypothesis. Similarly, Heckman, Layne-Farrar, and Todd (1996) who are critical on the assumption of linearity with respect to schooling suggested that a non-linear specification is more appropriate due to so-called 'sheepskin'. Griffin and Edwards (1993) showed the non-linearity in the returns to education in Brazil using the 1989's annual survey and found a large increment in earnings associated with four years of schooling. The results show that the largest single year incremental increase in earnings until one reaches 11 years of schooling.

Arabsheibani and Rees (1998) estimated non-linear returns to schooling in Libya and found that some non-diploma years also possess the same advantage of earnings. Patrinos (1996) did not support the sheepskin interpretation of the screening hypothesis, but he did suggests non-linearity in the returns to education in Guatemala. A recent study by Yunus (2017) found a little evident of sheepskin effects, whereas a university degree receives a greater rates of return in the Malaysian ICT sector. However, the returns to education showed a non-linear relationship between certificates of qualification and earnings. The returns of workers with Middle Certificate of Education/Vocational (MCE/MCEV) are higher than Higher School Certificate (HSC) and diploma workers during 2002-2007 period.

\section{DATA DESCRIPTION AND SCOPE OF STUDY}

The present study used the Malaysian Household Income Survey (HIS) for the year 2002, 2007, and 2012. The HIS was conducted by the Malaysian Economic Planning Unit (EPU) and Malaysian Department of Statistic (DOS). The HIS is 
one of the most comprehensive surveys of individuals' earnings in Malaysia, which are convenient to analyse the role of sheepskin effects in the returns to education at different certificate of qualification. This makes it an ideal data source for this research. This study focuses the period of 2002 to 2012. This is in line with our aims to oversee the changes in the trend of average private returns to education at different level of certificates of qualification between two phases, 2002-2007 and 2007-2012. This change could be seen in the next five years as a result of the implementation of skilled development project. The purpose of this study is to use the latest HIS data in 2012 to provide the latest information regarding the current condition of demand-supply in the Malaysian business services sector. Thus, it is not only helping the individuals' choices concerning level of qualifications, but might also extend to other individuals in the other Malaysia's economy. The latest HIS is also useful in providing valuable information to government for assessing the efficiency of public investment in education, especially in solving the problem of both educational mismatches (over-/under-education) in the Malaysian labour market. Both aspects may reflect inefficiencies in the allocation of resources.

As the purpose of this study is to investigate the sheepskin effects in the returns to education at different levels of certificates of qualification, there are several aspects that must be considered when performing sample selection. First, the number of people chosen is restricted to those employees who are between the ages of 15 and 64 in spite of the data collected by DOS which consists of individuals aged from 0 to 99 . Second, the sample selection in this study excludes individuals who did not attend school or those workers who have no formal educational qualifications. The sample also does not cover people who have received a traditional Islamic education or those, mainly migrant workers, who have qualifications which are not recognised in the Malaysian education system by the Ministry of Education. Third, the sample chosen is also restricted to employed individuals. They are employers and workers either in private or government sectors and thus, the self-employed or those who work on their account are excluded. The exclusion of the self-employed is because of the problems associated with the measurement of self-employment income. Similarly, for unpaid family workers or those who work without pay, housewives, those who look after the home, students, pensioners, children who not at school and those who have never worked are outright excluded from the sample. In addition, unpaid family workers may also be classed as self-employed. Based on the selection criteria, total sample size used in this study and the breakdown of the sample by individual's highest level of certificates in the business services sector are as shown in Appendices A and B respectively. 


\section{EMPIRICAL METHODOLOGY}

This section presents the empirical methodology used to investigate the returns to education in the Malaysian business services sector. The present study employs an extended Mincer model (1974) in which additional variables influencing earnings, apart from education, experience and years of schooling. The model is presented as follows:

$$
\ln W_{i t k}=\alpha_{0}+B_{0} \Sigma_{E} E d u_{i t k}+B_{1} \operatorname{Exp}_{i t k}+B_{2} \operatorname{Exp}_{i t k}^{2}+B_{3} Y_{\text {Years_sch }} \text { itk }_{1}+\gamma O C C_{i t k}+\varepsilon_{i t k}
$$

Where: $i$ indexes individuals $(i=1, \ldots, \mathrm{N}), t$ indexes time period of $(t=2002$, 2007, 2012), and $k$ represents a vector for business services sector, while $\ln W$ is the natural $\log$ of the yearly earnings of an individual. ${ }^{4} E d u$ is the level of educational attainment by $E$ types of highest certificates qualification obtained at school, college, or university. They are: university degree, diploma, HSC, MCEV/ MCE,${ }^{5}$ Lower Certificate of Education (LCE), primary, and below primary. The below primary classification is used as a reference group as this study is interested in finding the changes of returns to education for other certificates qualifications relative to below primary. EXP is the potential experience (age minus years of schooling-7). It reflects the assumption that a child begins schooling at the age of seven and starts working immediately after completing schooling; and this formula is akin to the Malaysian education policy of compulsory schooling for children beginning at the age of seven. $E X P^{2}$ is the quadratic of experience. It is used to capture the concavity of the experience earnings profile. ${ }^{6}$ Years_sch is a years of schooling according to HIS classification. It consists of year 1 (Standard 1) until more than year 15 (diploma/university). $O C C$ is another explanatory variable assumed to affect earnings. $O C C$ is a series of dummy variables which include representing occupation types created from the one-digit occupational code following the Malaysia Standard Classification of Occupations (MASCO) code 2008. The present study chooses the occupational variables as a control variable since the occupation is most closely associated with skills possessed and it is possible to explain the different returns to education at different levels of certificates qualification. The types of occupations and jobs undertaken by individuals differ in the requirement of skills and thus affecting the returns to education (Aslam, 2009).

The occupation category generally does not lead to major changes in the estimated returns to schooling which is lowering by around $1 \%$ and the effect of changes upon the returns to schooling is small (Blundell, Dearden, \& Sianesi, 2004). By including occupational controls, it is able to capture the return for overeducated workers (Harmon, Oosterbeek, \& Walker, 2003). Similarly in the present case 
study, even though the effect is small but it is significant in affecting the earnings. ${ }^{7}$ The detailed dependent, independent variables, and control variables including their summary statistics are shown in Appendix C.

As a common practice in the literature, the average private returns to education $\left(r_{i}\right)$ for each qualification level is measured by comparing the level below (Kenayathulla, 2013; Katz \& Murphy, 1992). It is calculated using the estimated ordinary least square (OLS) coefficients in the following way: $r_{i}=\left(B_{i}-B i_{-1}\right) /$ $\left(\mathrm{S}_{\mathrm{i}}-\mathrm{Si}_{-1}\right)$; where: $\mathrm{i}$ is the level of the highest certificate obtained. $\mathrm{S}_{\mathrm{i}}$ is the years of schooling at level of highest certificate qualification achieved. For instance, the returns to degree qualification is calculated as $\mathrm{r}($ degree $)=\left(B_{1}\right.$ degree $-B$ diploma $) /$ $\left(S_{1} 16.5-S 14.5\right)$. Note that the returns to degree level of qualification should be understood as the returns to graduation at degree qualification relative to the 16 years and above years of schooling. ${ }^{8}$ The detailed years of schooling according to level of highest certificate qualification are shown in Table 1.

Table 1

Years of schooling by level of highest certificate qualification

\begin{tabular}{cl}
\hline Years of schooling & Level of highest certificates of qualification \\
\hline 3 & Below primary (no certificate) - standard 1 to standard 3 \\
6 & Primary (no certificate) - standard 4 to standard 6 \\
9 & Lower Certificate Education \\
11 & Middle Certificate Education Vocational \\
13 & Higher School Certificate \\
$14-15$ & Diploma \\
$16-17$ & Degree and above \\
\hline
\end{tabular}

Source: MOHE (2010)

\section{ECONOMETRIC ANALYSIS}

In order to examine the relationship between education and earnings in the Malaysian business services sector, a series of earnings regressions are performed for the years 2002, 2007, and 2012. We differentiate, specifically, between human capital model versus 'signalling/screening' theories (sheepskin argument). Following convention, the natural logarithm of annual earnings, the baseline regression model, Model 1, is a straightforward extension of the Mincer equation, in which years of schooling is the independent variable of main interest. Model 1 is considered as a human capital model developed by Mincer (1974) which provides a linear relation between the logarithm of earnings and years of schooling, and 
interprets the coefficient of this variable as the return of one year of schooling. Nonetheless, the human capital model does not allow researchers to determine the nature of these returns. Hence, one of the more frequently used contrasts of the Screening model versus human capital theory is based on the so-called 'sheepskin argument' as shown in Models 2 and 3. Model 2 is considered as a 'hybrid model', as it nests the human capital model and the sorting model in which years of schooling and level of completed education at highest certificates of qualification (as defined in the Malaysian educational system) is represented by string of dummy variables for each year which are the independent variable (Ferrer \& Riddell, 2002).

Next, we perform Model 3 by replacing years of schooling by adding eight dummies for years of schooling ( $0-5$ years of schooling as a control variables) together with level of completed highest certificates of qualification. Model 3 may be considered a more powerful test for sheepskin effects than Model 2 (Pons \& Blanco, 2005; Belman \& Heywood, 1991, 1997; Hungerford \& Solon, 1987; Jaeger \& Page, 1996; Park, 1999).This model tests the sheepskin hypothesis by quantifying the returns to educational degrees net of years of schooling. This model argues that workers are rewarded not for the productive-enhancing contribution of schooling (human capital model), but rather for obtaining the certificate that comes with completing a particular level of schooling. Based on a sheepskin prediction that "wages will rise faster with extra years of schooling when the extra years also convey a certificate" (e.g.: Ferrer \& Riddell, 2002; Pons \& Blanco, 2005; Hungerford \& Solon, 1987; Jaeger \& Page, 1996; Park, 1999).

This study employs OLS estimators to analyse the returns to education at different levels of certificate qualifications in business services sector. The application of the OLS estimator in the present study is sufficient to interpret the result in line with the objective of this study in analysing the trend of returns to education at different levels of certificate certifications during the period of 2002 to 2012.

Although the methodology employed is only a regression analysis, but the outcome of this analysis still be able to provide preliminary picture about the role of sheepskin effects in the returns to education at different level of certificate certifications in the Malaysian business services sector. In order to deal with the heteroscedasticity problem due to unobserved heterogeneity, namely health and family background characteristics, the present study employed the OLS estimator using regression with a robust standard errors as suggested by Huber (1992). This technique was applied by Black, Devereux, and Salvanes (2003) to analyse employment earnings across industries. The result which was estimated using regression with a robust standard error is safe to deal with the heteroscedasticity problem because the structure of heteroscedasticity is usually unclear, especially in the researchers' 
case, where the sample size is large. Even if there is no heteroscedasticity issue, the robust standard errors become just conventional OLS standard errors. In fact, the robust standard errors are appropriate even under homoscedasticity. The robust standard errors option in regression was also efficient in dealing with normality minor problem because some observations might exhibit large residuals, leverage, or influence, as well as to capture the possible concerns about the effects of serial correlation on the standard errors (Black et al., 2003).

For analysis purposes, the regression result for all model had been performed. No further explanation was required for human capital model except years of schooling, but this was not the case for the level of completed education at highest certificates in Models 2 and 3. Hence, for Models 2 and 3, the average private returns to education at different level of certificates was calculated.

Next, this study performed the trend of average private returns to education between 2002 to 2007 and 2007 to 2012 for both Models 2 and 3. This is in line with the aim of this study to evaluate the changes in the private returns to education in the business services sector between 2002 to 2007 and 2007 to 2012. Private rates of return are used to explain the behaviour of individuals in seeking different levels and types of schooling. The present study differs from previous studies in Malaysia that it is not just providing additional insights to the human capital theory-sorting model, but this advances the analysis to examine how returns varied over the period, and how the returns varied according to the highest level of qualification obtained. For this purpose, following Kiker, Santos, and De Oliveira (1997), self-assessment method had been applied to measure whether both educational mismatches phenomena occur in the return at certificates of qualification by comparing the level of highest certificate qualification reached by individual with occupations. The statistic result for cross tabulation table between the level of certificates of qualification and occupational group is as shown in Appendix D.

\section{ECONOMETRIC RESULT}

In human capital model (Model 1), the results in Table 2 indicate that all independent variables are statistically significant to determine earnings. The main point is to report that one additional year of schooling increases gross yearly earnings by roughly $12.5 \%$ in 2002 . These results are in accordance with previous studies in Malaysia (e.g.: Kenayathulla, 2013). The years of schooling show an increasing trend by $36.8 \%$ between 2002 and 2012. This result is closely associated with government's effort to achieve a productivity-driven economy through human resource development and the use of knowledge-based education as a tool for 
employment restructuring. It is evident that the number of enrolment at tertiary education has increased over the years due to a higher level of educational attainment being strongly associated with a higher employment rate and being perceived as a gateway to better job opportunities and earnings (Yunus, 2014; Yunus \& Said, 2016).

Table 2

OLS regression analysis (human capital model): Annual earnings (logged) by years of schooling for business services sector employees, 2002-2012

\begin{tabular}{|c|c|c|c|c|c|c|}
\hline \multirow{3}{*}{ Wages } & \multicolumn{6}{|c|}{ Model 1} \\
\hline & \multicolumn{2}{|r|}{2002} & \multicolumn{2}{|r|}{2007} & \multicolumn{2}{|c|}{2012} \\
\hline & Coef. & Std. Err. & Coef. & Std. Err. & Coef. & Std. Err. \\
\hline Years_sch & 0.125 & $(0.009)^{* * *}$ & 0.128 & $(0.014)^{* * *}$ & 0.131 & $(0.007)^{* * *}$ \\
\hline EXP & 0.013 & $(0.004)^{* *}$ & 0.021 & $(0.008)^{* *}$ & 0.036 & $(0.006)^{* * *}$ \\
\hline $\mathrm{EXP}^{2}$ & 0.010 & $(0.000)^{* * *}$ & 0.015 & $(0.000)^{* *}$ & 0.015 & $(0.000)^{* * *}$ \\
\hline \multicolumn{7}{|l|}{ Certificates Levels } \\
\hline Primary & - & - & - & - & - & - \\
\hline $\mathrm{LCE}$ & - & - & - & - & - & - \\
\hline MCE/MCEV & - & - & - & - & - & - \\
\hline HSC & - & - & - & - & - & - \\
\hline Diploma & - & - & - & - & - & - \\
\hline University degree & - & - & - & - & - & - \\
\hline Prof & 0.321 & $(0.084)^{* * *}$ & 0.240 & $(0.111)^{* * *}$ & 0.345 & $(0.056)^{*}$ \\
\hline Tech \& Assc_prof & 0.826 & $(0.0735)^{*}$ & 0.772 & $(0.096)^{* *}$ & 0.842 & $(0.155)^{* * *}$ \\
\hline Manager & 0.103 & $(0.082)^{* *}$ & 0.335 & $(0.115)^{* *}$ & 0.287 & $(0.091)^{* *}$ \\
\hline Clerical & 0.573 & $(0.070)^{* * *}$ & 0.526 & $(0.099)^{* * *}$ & 0.138 & $(0.040)^{* * *}$ \\
\hline Sales & 0.365 & $(0.078)^{* * *}$ & 0.288 & $(0.0895)^{* * *}$ & 0080 & $(0.141)^{*}$ \\
\hline Agricultural & 0.051 & $(0.0665)^{*}$ & 0.618 & $(0.779)^{*}$ & 0.080 & $(0040)^{*}$ \\
\hline Craft_trade & 0.564 & $(0.123)^{* * *}$ & 0.607 & $(0.146)^{* * *}$ & 0.242 & $(0.015)^{*}$ \\
\hline Plant_machine & 0.551 & $(0.096)^{* * *}$ & 0.434 & $(0.116)^{* * *}$ & 0.156 & $(0.069)^{*}$ \\
\hline _cons & 6.857 & $(0.133)^{* * *}$ & 8.872 & $(0.223)^{* * *}$ & 8.001 & $(0.129)^{*}$ \\
\hline Observations & 1959 & & 761 & & 1643 & \\
\hline $\mathrm{R}^{2}$ & 0.378 & & 0.369 & & 0.3606 & \\
\hline \multicolumn{7}{|c|}{$\mathrm{H}_{\mathrm{o}}$ : Schooling level dummies $=0$} \\
\hline $\mathrm{H}_{1}$ : Schooling year & $\mathrm{es}=0$ & & & & & \\
\hline
\end{tabular}

Note: Huber/White robust standard errors are in parentheses

$* p<0.05 ; * * p<0.1$; *** $p<0.001$ 
Table 3

OLS regression analysis (hybrid model): Annual earnings according to years of schooling and level of certificates of qualification for employees in the business services sector, 2002-2012

\begin{tabular}{|c|c|c|c|c|c|c|}
\hline \multirow{3}{*}{ Wages } & \multicolumn{6}{|c|}{ Model 2} \\
\hline & \multicolumn{2}{|r|}{2002} & \multicolumn{2}{|r|}{2007} & \multicolumn{2}{|c|}{2012} \\
\hline & Coef. & Std. Err. & Coef. & Std. Err. & Coef. & Std. Err. \\
\hline Years_sch & 0.057 & $(0.033)^{*}$ & 0.059 & $(0.077)^{* *}$ & 0.062 & $(0.0230)^{*}$ \\
\hline \multicolumn{7}{|l|}{ Certificate Levels } \\
\hline Primary & 0.087 & $(0.332)^{* *}$ & 0.166 & $(0.7037)^{* *}$ & 0.184 & $(0.1887)^{*}$ \\
\hline LCE & 0.135 & $(0.024)^{*}$ & 0.241 & $(0.145)^{*}$ & 0.248 & $(0.122)^{*}$ \\
\hline MCE/MCEV & 0.214 & $(0.079)^{* * *}$ & 0.400 & $(0.162)^{* *}$ & 0.476 & $(0.085)^{* *}$ \\
\hline HSC & 0.338 & $(0.153)^{* * *}$ & 0.462 & $(0.3238)^{*}$ & 0.591 & 0.094 \\
\hline Diploma & 0.551 & $(0.219)^{* * *}$ & 0.526 & $(0.497)^{* * *}$ & 0.674 & $(0.091)^{* * *}$ \\
\hline University degree & 0.851 & $(0.221)^{* * *}$ & 0.672 & $(0.500)^{* *}$ & 0.851 & $(0.113)^{* *}$ \\
\hline EXP & 0.018 & $(0.004)^{* * *}$ & 0.020 & $(0.001)^{*}$ & 0.035 & $(0.006)^{* * *}$ \\
\hline $\mathrm{EXP}^{2}$ & 0.002 & $(0.000)^{* * *}$ & 0.002 & $(0.000)^{*}$ & 0.001 & $(0.000)^{* * *}$ \\
\hline Prof & 0.491 & $(0.085)^{* * *}$ & 0.376 & $(0.111)^{* * *}$ & 0.493 & $(0.084)^{* * *}$ \\
\hline Tech \& Assc_prof & 0.835 & $(0.074)^{* * *}$ & 0.795 & $(0.098)^{* * *}$ & 0.824 & $(0.069)^{* * *}$ \\
\hline Manager & 0.203 & $(0.0831)^{* * *}$ & 0.338 & $(0.120)^{* * *}$ & 0.424 & $(0.110)^{* * *}$ \\
\hline Clerical & 0.580 & $(0.0746)^{* * *}$ & 0.542 & $(0.104)^{* * *}$ & 0.368 & $(0.074)^{* * *}$ \\
\hline Sales & 0.348 & $(0.078)^{* * *}$ & 0.287 & $(0.092)^{* * *}$ & 0.366 & $(0.057)^{* * *}$ \\
\hline Agricultural & 0.077 & $(0.058)^{*}$ & 0.065 & $(0.062)^{* *}$ & 0.311 & $(0.139)^{* * *}$ \\
\hline Craft_trade & 0.548 & $(0.124)^{* * *}$ & 0.636 & $(0.152)^{* * *}$ & 0.454 & $(0.161)^{* * *}$ \\
\hline Plant_machine & 0.533 & $(0.096)^{* * *}$ & 0.466 & $(0.113)^{* * *}$ & 0.356 & $(0.079)^{* * *}$ \\
\hline \multicolumn{7}{|c|}{ Years of Schooling-Dropout (Dummy) } \\
\hline 6 years & - & - & - & - & - & - \\
\hline $7-8$ years & - & - & - & - & - & - \\
\hline 9 years & - & - & - & - & - & - \\
\hline 10 years & - & - & - & - & - & - \\
\hline 11 years & - & - & - & - & - & - \\
\hline 12 years & - & - & - & - & - & - \\
\hline 13 years & - & - & - & - & - & - \\
\hline $14-16$ years & - & - & - & - & - & - \\
\hline cons & 8.726 & $(0.425)^{*}$ & 9.863 & $(0.327)^{*}$ & 7.576 & $(0.321)^{*}$ \\
\hline Observations & 1959 & & 761 & & 1644 & \\
\hline $\mathrm{R}^{2}$ & 0.506 & & 0.389 & & 0.375 & \\
\hline $\mathrm{H}_{\mathrm{o}}$ : Schooling level dummies $=0$ & $\mathrm{~F}(16,1$ & $942)=114.69$ & $\mathrm{~F}(21$, & $39)=22.85$ & $\mathrm{~F}(25$, & $518)=43.24$ \\
\hline $\mathrm{H}_{1}$ : Schooling year dummies $=0$ & & & & & & \\
\hline
\end{tabular}

Note: Huber/White robust standard errors are in parentheses

$* p<0.05$;** $p<0.1 ; * * *<<0.001$ 
In hybrid model (Model 2), includes both years of schooling and level of completed education at highest certificates as shown in Table 3. The results reported that all educational level dummies education levels or degrees illustrated a positive relationship earnings during the period from 2002 to 2012. The coefficient for all degrees remained statistically and economically significant in Model 2 during the period of investigation.

It is interesting to report that when degrees are taken into account, the effect of years of schooling is reduced by more than $50 \%$ for employees in the business services sector. For instance, in 2002, the years of schooling had reduced by $54.4 \%$ [(0.057-0.125/0.057)*100]. The patterns remained for 2007 and 2012 which had reduced by $53.9 \%$ and $52.8 \%$ respectively. These result is consistent with the previous studies. For example, Bauer et al. (2005) found a reduction exceeding $50 \%$. All coefficient of degrees were reported higher than years of schooling in Model 2 during the period of investigation. This result demonstrated that that there were substantial sheepskin effects than accumulated years of schooling in determining the earnings in the Malaysian business services sector.

A notable finding to report about the non-linear relationship between education and earnings in Model 2 as shown in Table 4. The average private returns for MCE/ MCEV was reported higher than HSC during the period of 2002 to 2012. A similar observation could be seen in 2007 and 2012, which MCE/MCEV holders again enjoy the higher average private returns than HSC and diploma holders.

Table 4

Average private returns to education for employees in the business services sector, 2002-2012 (hybrid model)

\begin{tabular}{lrrrrrrr}
\hline \multirow{2}{*}{ Certificate Levels } & \multicolumn{3}{c}{ Model $(2)$} & & \multicolumn{2}{c}{$\%$ changes } \\
\cline { 2 - 3 } \cline { 6 - 7 } & 2002 & 2007 & 2012 & & $2002-2007$ & $2007-2012$ \\
\hline LCE & 1.58 & 2.52 & 2.15 & & 0.95 & -0.37 \\
MCE/MCEV & 3.95 & 7.92 & 11.39 & & 3.97 & 3.47 \\
HSC & 0.73 & 3.11 & 5.75 & & 2.38 & 2.64 \\
Diploma & 21.50 & 4.28 & 6.84 & & -17.22 & 2.56 \\
University degree & 15.03 & 7.31 & 12.87 & & -7.72 & 5.56 \\
\hline
\end{tabular}

At a higher level of education, diploma-educated workers enjoy the higher returns than degree holders in 2002, but the patterns of average private returns in Model 2 had changed between 2007 and 2012. The sheepskin effects from university degree were higher than other credentials. 
In terms of the trend of average private returns, the first phase, 2002-2007, was reported. Table 4 reveals that workers at all qualifications increased in their trends except for degree and diploma credentials. The trend of average private returns for workers with MCE/MCEV recorded the highest return by $3.97 \%$ as compared to their counterparts. This result clearly indicated that the labour market in Malaysian business services sector remained favourable for semi-skilled workers with the demand for workers with MCE qualifications increased by 18.5\% between 2002 and 2007 (see Appendix D). The highest proportion of workers with MCE/ MCEV qualifications concentrates in clerical and sales and services occupational groups. Both clerical and sales and services occupational groups also showed the increasing trend by $6.1 \%$ and $7.7 \%$ respectively over the same period. Empirically, this result supported the claim that the average private returns for workers are much higher when there is a match between the skills supplied/education profile with the firm's demand compared to workers who are over-educated or undereducated (Freeman,1977; Lamo \& Messina, 2010; Quintini, 2011).

Note further in Model 2, there was a declining trend for diploma- and degreecertified during the period of 2002 to 2007 . Both degree and diploma workers declined in their trends by $7.22 \%$ and $17.22 \%$ respectively as indicated in Table 4. The over-education occurring for degree credentials could be evidenced as a plausible reason regarding the decreasing returns during the period of 2002 to 2007. As can be seen in Appendix D, the demand for workers with degree qualifications for clerical occupation increased by $0.2 \%$ but, there was a decrease in demand for professional occupation at degree qualification by $6.6 \%$ in $2002-2007$. This results are supportive of signalling hypothesis that claims the declining return to education is due to the inability of the highly educated to persistently maintain their productivity-unrelated earnings advantage over the less educated (Groot \& Oosterbeek, 1994; Spence, 1973). Many evidences supporting the returns for workers fall because they might be dissatisfied with their current job and dropped their productivity level in the firm (Green \& Zhu, 2010; Murillo, Rahona-López, \& Salinas-Jiménez, 2012; Verhaest \& Omey, 2006).

Meanwhile, for diploma holders, this study suggested that the declining return is due to a short fall in the skills available among workers in adapting to the dynamic and evolving nature of the industry, as well as the emerging new technology that keep changing over time. Also, the demand for technician and associate professional declined by $4.3 \%$ between 2002 and 2007 (see Appendix D). Consequently, the requirements for any new entrées into an industry might have been advanced and the workers who are already employed appear to be under-skilled. ${ }^{9}$ Consistently, a study by Productivity Investment Climate Survey (PICS) in 2002 and 2007 found 
that the percentage of workers with diplomas believed that their level of education mismatched the level required by their occupation and had increased from $8.4 \%$ in 2002 to $10.4 \%$ in 2007. Also, it tends to be under-qualified (EPU \& World Bank, 2007).

For the second phase, 2007-2012, the estimation result in Table 4 showed that the trend of average private returns increased for all certificates except for LCE in 2007-2012. The results indicated that the employers might pay for certificates if they adequately signal worker productivity; that is, if they act as proper sheepskins.

Next, Table 5 reports the results obtained from estimating Model 3. Using dummy variables for years of schooling, the present study tests the sheepskin hypothesis by quantifying the returns to educational degrees net of years of schooling. Two main findings were found to be noteworthy in Model 3 for the first phase, 20022007. The first feature to be noted is that even though Model 3 is more powerful to test the sheepskin effects than Model 2, the present study did not find significant sheepskin effects on earnings as compared to Model 2 in 2002 and 2007. It can be seen clearly in which the coefficient of sheepskin effects associated with various certificate levels decreased between 2002 and 2007 than Model 2. For instance, the coefficient for university degree in Model 3 decreased from Model 2 by $0.157 \%$ and $0.041 \%$ respectively in 2002 and 2007. It was estimated that the results indicated that certificate effects are limited to workers in the business services sector from 2002 to 2007.

Second, the results in Table 5 showed that the point estimates in Model 3 for the returns to years of schooling are higher for 14-16 years of schooling. The trend for years of schooling for university dropout increased $11.8 \%$ between 2002 and 2007. ${ }^{10}$ The results in Model 3 showed that years of schooling for university dropout's coefficient in 2007 is also reported higher than sheepskin effects from degree university. These results suggested that being accepted to attend university without certificate provides a 'signalling value' for employer, which is comparable to the signalling value of receiving credentials degrees. Hence, employers can reduce the role of education as a signal. This finding which is consistent with the signalling theory asserts that education acts just as a signal to employer to sort out the most productive workers or as an indication of innate ability. However, education is not the main signal to employers to pay higher wages or returns. The higher returns paid to employees were based on labour productivity (Spence, 1973; Weiss, 1995). The years of schooling might also be rewarded as a reflection of their productive-enhancing contribution (Mincer \& Polachek, 1974). 
Table 5

OLS regression analysis (sheepskin effects model): Annual earnings according to the level of certificates of qualification and dummy variables for the number of years of schooling in the business services sector, 2002-2012

\begin{tabular}{|c|c|c|c|c|c|c|}
\hline \multirow{3}{*}{ Wages } & \multicolumn{6}{|c|}{ Model 3} \\
\hline & \multicolumn{2}{|r|}{2002} & \multicolumn{2}{|r|}{2007} & \multicolumn{2}{|r|}{2012} \\
\hline & Coef. & Std. Err. & Coef. & Std. Err. & Coef. & Std. Err. \\
\hline Years_sch & - & - & - & - & - & - \\
\hline \multicolumn{7}{|l|}{ Certificate Levels } \\
\hline Primary & 0.065 & $(0.002)^{*}$ & 0.051 & $(0.063)^{* *}$ & 0.210 & $(0.014)^{* *}$ \\
\hline LCE & 0.140 & $(0.010)^{*}$ & 0.221 & $(0.658)^{*}$ & 0.236 & $(0.321)^{*}$ \\
\hline MCE/MCEV & 0.237 & $(0.203)^{* *}$ & 0.375 & $(0.622)^{* *}$ & 0.483 & $(0.050)^{*}$ \\
\hline HSC & 0.301 & $(0.216)^{*}$ & 0.499 & $(0.089)^{*}$ & 0.628 & $(0.036)^{*}$ \\
\hline Diploma & 0.491 & $(0.015)^{*}$ & 0.568 & $(0.015)^{*}$ & 0.776 & $(0.042)^{*}$ \\
\hline University degree & 0.694 & $(0.204)^{* *}$ & 0.631 & $(0.100)^{* *}$ & 0.976 & $(0.025)^{* * *}$ \\
\hline EXP & 0.014 & $(0.004)^{* * *}$ & 0.021 & $(0.008)^{* *}$ & 0.032 & $(0.006)^{* * *}$ \\
\hline $\mathrm{EXP}^{2}$ & -0.002 & $(0.000)^{* * *}$ & -0.001 & $(0.000)^{* * *}$ & 0.001 & $(0.000)^{* * *}$ \\
\hline Prof & 0.596 & $(0.087)^{* * *}$ & 0.426 & $(0.110)^{*}$ & 0.519 & $(0.083)^{* * *}$ \\
\hline Tech \& Assc_prof & 0.848 & $(0.077)^{*}$ & 0.768 & $(0.096)^{* *}$ & 0.835 & $(0.071)^{* * *}$ \\
\hline Manager & 0.208 & $(0.084)^{* * *}$ & 0.300 & $(0.117)^{*}$ & 0.447 & $(0.111)^{* * *}$ \\
\hline Clerical & 0.593 & $(0.076)^{* * *}$ & 0.522 & $(0.101)^{* *}$ & 0.349 & $(0.074)^{* *}$ \\
\hline Sales & 0.356 & $(0.0797)^{* * *}$ & 0.288 & $(0.089)^{* * *}$ & 0.364 & $(0.057)^{* *}$ \\
\hline Agricultural & -0.067 & $(0.058)^{*}$ & -0.058 & $(0.089)^{*}$ & 0.308 & $(0.043)^{* *}$ \\
\hline Craft_trade & 0.576 & $(0.1280)^{* *}$ & 0.596 & $(0.153)^{*}$ & 0.415 & $(0.015)^{* * *}$ \\
\hline Plant_machine & 0.554 & $(0.098)^{* * *}$ & 0.426 & $(0.129)^{*}$ & 0.352 & $(0.008)^{* * *}$ \\
\hline \multicolumn{7}{|c|}{ Years of Schooling-Dropout (Dummy) } \\
\hline 6 years & 0.190 & $(0.084)^{*}$ & 0.080 & $(0.024)^{*}$ & 0.149 & $(0.018)^{* * *}$ \\
\hline $7-8$ years & 0.044 & 0.023 & 0.044 & 0.189 & 0.146 & $(0.025)^{* * *}$ \\
\hline 9 years & 0.009 & 0.053 & -0.038 & 0.067 & 0.079 & $(0.034)^{*}$ \\
\hline 10 years & -0.028 & 0.051 & 0.016 & 0.172 & 0.178 & $(0.0431)^{* *}$ \\
\hline 11 years & 0.343 & $(0.044)^{*}$ & 0.535 & $(0.060)^{* *}$ & 0.611 & $(0.045)^{* *}$ \\
\hline 12 years & -0.026 & $(0.144)^{* *}$ & 0.418 & $(0.085)^{*}$ & 0.190 & $(0.044)^{*}$ \\
\hline 13 years & 0.512 & $(0.039)^{* *}$ & 0.537 & $(0.761)^{* *}$ & 0.677 & $(0.259)^{* *}$ \\
\hline $14-16$ years & 0.551 & $(0.034)^{* *}$ & 0.659 & $(0.057)^{*}$ & 0.622 & $(0.029)^{*}$ \\
\hline cons & 7.858 & $(0.320)^{* * *}$ & 10.499 & $(0.402)^{*}$ & 8.156 & $(0.548)^{* *}$ \\
\hline Observations & 1959 & & 761 & & 1644 & \\
\hline $\mathrm{R}^{2}$ & 0.490 & & 0.373 & & 0.374 & \\
\hline \multicolumn{7}{|l|}{$\mathrm{H}_{\mathrm{o}}:$ Schooling level dummies $=0$} \\
\hline $\mathrm{H}_{1}$ : Schooling year dummies $=0$ & $\mathrm{~F}(23,1$ & $935)=81.98$ & $\mathrm{~F}(16,1$ & $626)=63.46$ & $\mathrm{~F}(22,1$ & $621)=47.14$ \\
\hline
\end{tabular}

Note: Huber/White robust standard errors are in parentheses

$* p<0.05 ; * * p<0.1 ; * * *<<0.001$ 
In terms of average private returns, this study found the similar result as reported in Model 2, which is a declining trend for the average private returns for both sheepskin effects from diploma and degree by $8.07 \%$ and $7.0 \%$ respectively from 2002 to 2007. This is shown in Table 6. Apart from over-education, the main reason for declining the trend of returns for both higher level of education as we found in Model 2, the results from this study support the learning hypothesis that the signalling effects should decline with increasing tenure because employers gradually obtain better information on the actual productivity of a worker (Bauer et al., 2005). Hence, it appears that there are no sheepskin effects in the sense of abnormally high returns to those with a university degree.

Table 6

Average private returns to education for employees in the business services sector, 2002-2012 (sheepskin effects model)

\begin{tabular}{lrrrrrrr}
\hline \multirow{2}{*}{ Certificate Levels } & \multicolumn{3}{c}{ Model (3) } & & \multicolumn{2}{c}{ \% changes } \\
\cline { 2 - 3 } \cline { 6 - 7 } & 2002 & 2007 & 2012 & & $2002-2007$ & $2007-2012$ \\
\hline LCE & 2.49 & 5.66 & 0.86 & & 3.17 & -4.80 \\
MCE/MCEV & 4.87 & 7.71 & 12.36 & & 2.83 & 4.65 \\
HSC & 3.20 & 6.19 & 7.22 & & 2.99 & 1.03 \\
Diploma & 12.68 & 4.61 & 9.88 & & -8.07 & 5.28 \\
University degree & 10.15 & 3.15 & 10.00 & & -7.00 & 6.85 \\
\hline
\end{tabular}

Next, the attention had now been diverted to the estimation result in Model 3 between 2007 and 2012. This study discovered similar result in Model 2 for estimation in Model 3 with the largest individual sheepskin effect associated with university degree. The coefficient of university degree increased by $36.6 \%$ [ $(0.976$ $\left.-0.694 / 0.976)^{*} 100\right]$. It is interesting to note that results in Table 5 also showed that all certificates are positive and statistically significant with earning. Another notable finding to highlight here is, the result in Model 3 also shows little evidence in the importance of years of schooling between 2007 and 2012 as stated in human capital theory. The coefficient of years of schooling in Model 3 showed a positive return and increased in their trend except for 6 years and 9 years of education between 2002 and 2012. However, the returns to educational degrees is clearly exceeding the returns to years of schooling.

Table 6 presents the average private returns for Model 3 that has dummy variables for each years of schooling. Even though the estimation in Table 6 showed the MCE/MCEV degree enjoys the largest average private returns, but, the trend of returns prove that the demand for degree and diplomas remains higher than other credentials. Both degree and diploma showed the largest increased in their trends 
by $6.85 \%$ and $5.28 \%$ respectively during the period of 2007 to 2012 . It also can be proven that the demand for both degree and diploma increased by $21.5 \%$ and $22.5 \%$ between 2007 and 2012 (see Appendix D). One of the important features of the structural transformation economy from 2007 to 2012 is that the economy has increasingly demanded higher-skilled workers. This was accompanied by broad occupational employment shifts that were skills-biased in nature. The growing importance of the services sector, which on the whole are more skill-intensive than the agricultural and manufacturing sectors, yielded the trajectory of a strong skilled labour demand. For professional occupation, there are two components that contribute to the demand for professional occupation which are technological change and domestic demands. Technological progress in an economy certainly also changes the requirements for economy's labour force in terms of knowledge level and skill combination and causes replacement of some occupation by other. Among the domestic demands, expansion in the private consumption and government consumption explain the most for the positive growth in professional occupation. The data in Appendix D also demonstrated that the demand for professional occupation with degree education level increased by $6.8 \%$ between 2007 and 2012.

\section{CONCLUSION, POLICY IMPLICATION, AND LIMITATION OF STUDY}

This study applied both human capital and sheepskin effects models to differentiate between the returns to schooling from mere years of schooling as a reflection of their productive-enhancing contribution (the case put by human capital theory) and the returns to education from academic certificates as signals of the individual's ability (sheepskin argument) in the Malaysian business services sector during the period of 2002 to 2012. The overall result shows that sheepskin effects of receiving university degree is served as a higher signal of productivity than other credentials from 2002 to 2012. It is interesting to point the effects of credentials at diploma and university degree are different between two phases: 2002-2007 and 2007-2012. Between 2002 and 2007, the result in this study showed that sheepskin effects for diploma and degree are limited to provide higher signal to employers in the business services sector. It is evidenced by the decline of the average private returns for both diploma and degree-educated over the same period. Over-education situations are found for degree case, and under-skilled problems are reported for diploma holders as a plausible reason of declining average private returns between 2002 and 2007.

Due to this problem, this study found that employer might believe that workers who are accepted to attend university without certificate, and workers with high 
and secondary dropout has a signalling value for employer, which is comparable to the signalling value of receiving a credential degree. The result in this study proves that the coefficient of returns to years of schooling is also reported higher than all credentials, with the returns for 16 years of schooling (university dropout) increased by $11.8 \%$ between 2002 and 2007 .

However, the patterns of sheepskin effects between 2007 and 2012 are significantly different from 2002 and 2007. In line with existing studies, this study consistently found that credential effects brought about some substantial earnings than years of schooling, with the largest individual sheepskin effect is associated with university degree (Ferrer \& Riddell, 2002; Mora \& Muro, 2008; Thrane, 2010). Also, the trend of average private returns showed the increased trend for all certificates except for LCE. This indicates that the employers might pay for certificates if they adequately signal worker's productivity by acting as proper sheepskins.

Lastly, the overall result in this study found a somewhat of a non-linear relationship between education and earnings. This is a return to MCE/MCEV holders which is higher than HSC holders during the period of investigation. Hence, the assumption that the average private returns to additional years of schooling is the same regardless of education level. This is not necessarily valid in Malaysian cases (Kenayathulla, 2013). In light of the importance of certificates of qualification to determine the individual's success in increasing their lifetime earnings, this study draws attention to the need for institutions of higher learning (IHL) and college to conduct their own analyses to assess the economic value of their degree programmes when contemplating programme elimination, expansion, and reform in order to increase the graduate employability.

This study suggests the IHL to put more effort to improve and expand the information about the labour market value of individual courses at individual institutions. Also, it is suggested that the university itself must have its own database to gather information and put extra effort to improve and expand the information about the needs of the labour market according to the course of study. Parents and employers increasingly see reliable and comparable information on graduate employability to prospective students as an effective way in aligning the future of supply and demand for higher qualified people. This is considered as the most effective way in anchoring labour market needs in higher institution provision. The development of a database managed by a special body appointed by the government is also needed in Malaysia, as the current labour market information is collected by various independent agencies. This might lead to inaccuracies in the analysis of current and future labour demand-supply according to their field of study. In order to overcome over-education and under-skilled problems to continue to occur in the 
future labour market, this study suggests industries to extend their interaction with IHL and government agencies during the curriculum review and development of academic courses. ${ }^{11}$ The strategy must be reinforced by law through compulsory requirement for industries or other bodies to engage with IHL.

Some financial incentives like tax breaks or subsidies are also important to implement the recognition by the cooperation as it helps in covering the cost of training. In making these efforts imperative, the related ministerial and IHL should make this strategy as one of the key performance indicator criteria for the institution. This effort enables the IHL's curriculum to meet specific industry needs and enables the university to provide workplace with ready and able talents.

Like most other research studying this particular subject, the present study is also subjected to a number of limitations. One of the limitations of this study is that the regression analyses might be biased via the omission of ability variables or other factors correlated with degree completion. Some of the studies highlighted by other studies such as Psacharopoulos and Layard (1979) controlled for IQ or other ability measures and family background, which are not available in the present study's data set. It is doubted, however, that this accounts for the discrepancy in results on sheepskin effects. These variables can be used as an instrument to expunge the endogeneity of schooling variable because an individual's choice of years of schooling and schooling decision tends to be correlated with the unobservable elements in the error in term of the earnings function. This in turn affects the average private returns to education (Angrist \& Krueger, 1991).

\section{ACKNOWLEDGEMENTS}

The author would like to thank Universiti Sains Malaysia for funding this project under the Short-Term Research Grant Scheme No. 304/PJJAUH/6313248. The author also would like to thank the Department of Statistics, Malaysia for providing the Household Income Survey data. The author is responsible for remaining errors.

\section{NOTES}

1. The empirical labour literature often refers returns to specific credentials of education as sheepskin effects. Sheepskin effects refer to gains in earnings associated with the completion of a diploma or degree, controlling for years of schooling. The estimation based on the highest level of schooling completed (credentials) is more accurate, 
because it provides an alternative structure for recovering the returns to schooling (Harmon et al., 2003).

2. According to the 2011 Graduate Tracer Study (GTS) conducted by the Ministry of Education, $27 \%$ of graduates from IHL were still unemployed one year after graduation. This percentage went up to $28 \%$ for private IHL and down to $17 \%$ among community college graduates. More than half of graduates with diploma holders especially in the technical areas are jobless almost for nine months each year after their graduation.

3. Over-education/over-qualification refers to the situation in which individuals are employed in jobs that do not require their current qualifications or the skills they have are higher than the skills required for the job. Under-education/under-qualification refers to workers whose qualifications are lower than that required by their occupation (Kiker et al., 1997; Hung, 2008; Quintini, 2011). In this study, we measure both over- and under-educational mismatches by referring to the concept of skill level by education qualifications as set up by Malaysia Standard Classification of Occupations (MASCO) code 2008 (see Appendix E).

4. The natural log of the yearly earnings of an individual is represented by $\ln \mathrm{W}$. Income earnings from paid employment may be received in cash or in kind as goods and services. These include direct wages and salaries for time worked and work done, cash bonuses and gratuities, commissions and tips, directors' fees, profit-sharing bonuses, and other forms of profit-related payments, and goods and services provided free or subsidised by the employer (including free food/concession).

5. This study combined MCE/MCEV as secondary education following the DOS classification. This was due to the number of years of schooling for MCE/MCEV being the same at 11 years. However, the questionnaires designed for HIS are separated for MCE and MCEV respectively in order to differentiate between those who have received technical skills from vocational schools.

6. In calculating experience, the value is obtained after taking the exponential value of the coefficients in the OLS model and minus 1 and then multiply by 100 . For instance, the value is obtained as follows: $\left.[\exp (0.058)-1)^{*} 100=(1.061-1)^{*} 100\right]=6.1 \%$

7. The robustness test had been conducted by including the occupational variables into model. By including the occupational variables, the coefficient of degrees coefficient becomes positive association with earnings.

8. The level of formal education (below primary and primary) are utilised for noncertificate level group. Following Kenayathulla (2013), the below primary and primary is referred to Standard 3 and Standard 6 respectively. Average years of completed education is used for both diploma and degree levels as the certificate of completion study is depending on the individual's field of study and specialisation. The diploma and degree are expected to be completed in 3 to 3.5 years and 3 to 5 years respectively in Malaysia. The HIS data do not contain the information of individual's field of study as well as years of schooling taken by an individual to complete their studies for obtaining the highest certificates of qualification. In Malaysia, MCE is a compulsory examination for students to go into tertiary education. It enables students either to go on to advanced level matriculation and the HSC subsequently, or to take diploma courses and then degrees afterwards. Calculation of years of education for diploma and degree education levels by MOHE is started after MCE with several assumptions. 
9. Under-skilled refers to skills supplied by workers that are below those required by their job (workers report that they need further training to cope well with their duties at work) (Desjardins \& Rubenson, 2011).

10. In this study, the selected sample for 'dropout' refers to people who just left school in a particular years and do not receive the highest certificate. This is to distinguish between those with the highest certificate and non-completers even though having the same years of schooling. In the case of tertiary education, in the HIS survey people are classed as having tertiary education if they hold a diploma or degree qualifications. Tertiary education does not necessarily mean people take studies at university level. They may be accepted into the university but did not complete their study to obtain the highest certificate either diploma or degree. Similarly, for secondary dropout, those with secondary education (Form 3) do not necessarily have the LCE. This may likely occur because people perhaps did not complete their schooling or they left school before sitting for the examinations that would enable them to obtain a certificate.

11. A survey by Institute of Strategic and International Studies (ISIS) Malaysia in business services sector in 2013 sector shows that $60 \%$ of organisations admitted that they do not work closely with learning institutions to improve the quality and quantity manpower supply. Sixty eight per cent stated that they do not work closely with government agencies/bodies to enhance the attraction of identification of critical jobs to the industry. 


\section{APPENDICES}

\section{Appendix A}

The number of people surveyed

\begin{tabular}{ccc}
\hline Year & Full sample & Number of sample taken \\
\hline 2002 & 178,300 & 60,009 \\
2007 & 86,381 & 47,043 \\
2012 & 27,902 & 18,806 \\
\hline
\end{tabular}

\section{Appendix B}

Distribution of workers (paid employment) by highest certificates of qualification achieved in the business services sector (\%), 2002-2012

\begin{tabular}{lrrr}
\hline Qualification & 2002 & 2007 & 2012 \\
\hline Lower Certificate Education (LCE) & 10.0 & 19.2 & 15.32 \\
Middle Certificate Education/Vocational (MCE/MCEV) & 32.0 & 39.1 & 45.97 \\
Higher School Certificate (HSC) & 3.6 & 3.5 & 4.72 \\
Diploma & 14.4 & 3.2 & 9.51 \\
Degree & 18.3 & 12.9 & 12.42 \\
No certificate (primary \& below primary) & 21.3 & 21.9 & 7.02 \\
\hline
\end{tabular}




\section{Appendix C}

Definition of variable and summary statistics






\section{Appendix D}

Self-assessment method for over-and under-educational mismatches: Level of highest certificate of qualification and types of occupations in the business services sector

\begin{tabular}{|c|c|c|c|c|c|c|c|c|c|c|c|}
\hline \multicolumn{11}{|c|}{2002} & \\
\hline Qualification & PROF & MANG & $\begin{array}{l}\text { TECHN. } \\
\& \text { PROF }\end{array}$ & CLRC & SALES & AGRI & CRAFT & $\begin{array}{l}\text { PLANT } \\
\& \text { MACH }\end{array}$ & ELEM & TOTAL & \\
\hline LCE & 0.3 & 0.3 & 1.2 & 1.2 & 2.3 & 0.7 & 1.2 & 1.3 & 2.8 & 10.0 & \\
\hline $\mathrm{MCE} / \mathrm{V}$ & 2.0 & 2.4 & 7.2 & 12.1 & 3.1 & 0.0 & 1.5 & 1.4 & 2.1 & 31.8 & \\
\hline HSC & 0.5 & 0.7 & 0.8 & 1.2 & 0.1 & 0.0 & 0.1 & 0.0 & 0.2 & 3.6 & \\
\hline Diploma & 3.9 & 2.5 & 5.1 & 2.7 & 0.1 & 0.0 & 0.0 & 0.0 & 0.1 & 14.4 & \\
\hline $\begin{array}{l}\text { University } \\
\text { Degree }\end{array}$ & 10.0 & 5.5 & 1.7 & 0.8 & 0.2 & 0.0 & 0.1 & 0.0 & 0.0 & 18.3 & \\
\hline $\begin{array}{l}\text { Primary/ } \\
\text { below } \\
\text { primary }\end{array}$ & 0.2 & 0.7 & 1.8 & 0.4 & 5.2 & 0.3 & 1.3 & 2.1 & 8.6 & 20.6 & \\
\hline Total & 16.9 & 12.1 & 17.8 & 18.4 & 11.0 & 1.0 & 4.2 & 4.8 & 13.8 & 100.00 & \\
\hline \multicolumn{12}{|c|}{2007} \\
\hline Qualification & PROF & MANG & $\begin{array}{l}\text { TECHN. } \\
\& \text { PROF }\end{array}$ & CLRC & SALES & AGRI & CRAFT & $\begin{array}{l}\text { PLANT } \\
\& \text { MACH }\end{array}$ & ELEM & TOTAL & $\begin{array}{c}\text { Changes } \\
\text { 2002-2007 } \\
(\%)\end{array}$ \\
\hline LCE & 0.1 & 0.5 & 1.5 & 0.8 & 9.0 & 0.0 & 1.4 & 1.4 & 4.5 & 19.2 & 9.2 \\
\hline $\mathrm{MCE} / \mathrm{V}$ & 2.4 & 3.7 & 8.8 & 6.8 & 10.8 & 0.2 & 0.2 & 0.2 & 4.2 & 39.1 & 7.3 \\
\hline HSC & 0.1 & 0.4 & 2.0 & 0.6 & 0.2 & 0.0 & 0.0 & 0.1 & 0.1 & 3.5 & -0.1 \\
\hline Diploma & 1.0 & 0.5 & 0.8 & 0.4 & 0.5 & 0.0 & 0.1 & 0.2 & 0.0 & 3.5 & -10.9 \\
\hline $\begin{array}{l}\text { University } \\
\text { Degree }\end{array}$ & 3.4 & 3.7 & 4.1 & 1.0 & 0.3 & 0.0 & 0.1 & 0.1 & 0.1 & 12.8 & -5.5 \\
\hline $\begin{array}{l}\text { Primary/ } \\
\text { below } \\
\text { primary }\end{array}$ & 0.4 & 0.2 & 1.6 & 0.3 & 9.0 & 0.1 & 0.8 & 1.4 & 8.1 & 21.9 & 1.3 \\
\hline Total & 7.4 & 9.0 & 18.8 & 9.9 & 29.8 & 0.3 & 2.6 & 5.2 & 17.0 & 100.0 & \\
\hline \multicolumn{12}{|c|}{2012} \\
\hline Qualification & PROF & MANG & $\begin{array}{l}\text { TECHN. } \\
\& \text { PROF }\end{array}$ & CLRC & SALES & AGRI & CRAFT & $\begin{array}{l}\text { PLANT } \\
\& \text { MACH }\end{array}$ & ELEM & TOTAL & $\begin{array}{c}\text { Changes } \\
2007-2012 \\
(\%)\end{array}$ \\
\hline LCE & 0.5 & 0.2 & 0.6 & 0.6 & 7.4 & $\begin{array}{l}0.0 \\
0.5\end{array}$ & 0.6 & 2.5 & 4.6 & 17.0 & 7.8 \\
\hline $\mathrm{MCE} / \mathrm{V}$ & 1.5 & 1.1 & 1.5 & 5.3 & 23.2 & 0.6 & 0.7 & 3.0 & 4.7 & 41.6 & 34.3 \\
\hline HSC & 0.3 & 0.2 & 0.9 & 1.1 & 1.4 & 0.0 & 0.1 & 0.3 & 0.2 & 4.5 & 4.6 \\
\hline Diploma & 3.2 & 0.6 & 4.9 & 1.4 & 1.2 & 0.1 & 0.0 & 0.0 & 0.2 & 11.6 & 22.5 \\
\hline $\begin{array}{l}\text { University } \\
\text { Degree }\end{array}$ & 10.2 & 2.1 & 2.5 & 0.5 & 0.5 & 0.2 & 0.0 & 0.0 & 0.0 & 16.0 & 21.5 \\
\hline $\begin{array}{l}\text { Primary/ } \\
\text { below } \\
\text { primary }\end{array}$ & 0.3 & 0.2 & 0.4 & 0.2 & 3.8 & 0.3 & 0.3 & 0.5 & 3.3 & 9.3 & 8.0 \\
\hline Total & 16.0 & 4.4 & 10.8 & 9.1 & 37.5 & 1.2 & 1.7 & 6.3 & 13.0 & 100.0 & \\
\hline
\end{tabular}




\section{Appendix E}

\section{The concept of skill level by education qualifications}

The two main concept used in occupational classification are the concept of the kind of work performed or job and the concept of skill. The use of the educational categories to define the four skill levels does not mean that the skill necessary to perform the tasks and duties of a given occupation can be acquired through formal education. The skills may be, and often are, acquired through informal training and experience. So, when classifying an occupation as for example engineer, it does not mean that the post can only be occupied by a formal, registered engineer, although the activities will correspond quite close to those undertaken by the said engineer. In addition, the focus is on the skills required to carry out the tasks and duties and not on whether a worker having a particular occupation is more or less skilled than another worker in the same occupation. The Major Group of the MASCO 2008 can be categorised according to the following four common skill levels:

\begin{tabular}{|c|c|c|}
\hline Skill level & Educational level & Major groups \\
\hline Fourth & $\begin{array}{l}\text { Tertiary education leading to a } \\
\text { university or postgraduate } \\
\text { university degree; Malaysian } \\
\text { Skills Advanced Diploma } \\
\text { (DLKM) Levels 5-8 }\end{array}$ & 1. Professionals \\
\hline Third & $\begin{array}{l}\text { Tertiary education leading to an } \\
\text { award not equivalent to a first } \\
\text { university level; Malaysian } \\
\text { Skills Certificate (SKM) Level 4, } \\
\text { or Malaysian Skills Diploma } \\
\text { (DKM) Level } 4\end{array}$ & 2. Technicians and associate professionals \\
\hline Second & $\begin{array}{l}\text { Secondary or post-secondary } \\
\text { education; Malaysian Skills } \\
\text { Certificate (SKM) Levels 1-3 }\end{array}$ & $\begin{array}{l}\text { 3. Clerical support workers } \\
\text { 4. Service and sales workers } \\
\text { 5. Skilled agricultural, forestry and fishery } \\
\text { workers } \\
\text { 6. Craft and related trades workers } \\
\text { 7. Plant and machine operators and } \\
\text { assemblers }\end{array}$ \\
\hline First & Primary education & 8. Elementary occupations \\
\hline
\end{tabular}

However, the concept of skill level is not applicable to Major Group 1: Managers; and Major Group 0: Armed forces occupations. For these two groups, the skill level concept does not reflect the main skill requirements for distinguishing them from other Major Group. 


\section{REFERENCES}

Alba-Ramírez, A., \& San Segundo, M.J. (1995). The returns to education in Spain. Economics of Education Review, 14(2), 155-166. https://doi.org/10.1016/02727757(95)90395-O

Angrist, J.D., \& Krueger, A.B. (1991). Does compulsory school attendance affect schooling and earnings? Quarterly Jurnal of Economic, 106, 979-1014. https://doi.org/10.2307/2937954

Arabsheibani, G.R., \& Rees, H. (1998). On the weak vs strong version of the screening hypothesis: A re-examination of the P-test for the U.K. Economics of Education Review, 17(2), 189-192. https://doi.org/10.1016/S0272-7757(97)00020-4

Aslam, M. (2009). Education gender gaps in Pakistan: Is the labor market to blame? Economic Development and Cultural Change, 57(4), 747-784. https://doi. org $/ 10.1086 / 598767$

Bañuls, A.L., \& Ramón Rodríguez, A.B. (2005). Returns on education in the Spanish tourism labour market. Tourism Economics, 11(1), 119-132. https://doi.org/ 10.5367/0000000053297176

Bauer, T.K., Dross, P.J., \& Haisken-Denew, J.P. (2005). Sheepskin effects in Japan. International Journal of Manpower, 26(4), 320-335. https://doi.org/ $10.1108 / 01437720510609528$

Beblavy, M., Teteryatnikova, M., \& Thum, A.-E. (2013). Expansion of higher education and declining quality of degrees. NEUJOBS Working Paper (Vol. 4.4.2. B). Retrieved from https://ssrn.com/abstract=2402692 \& https://doi.org/10.2139/ssrn. 2402692

Becker, G.S. (1962). Investment in human capital: A theoretical analysis. The Journal of Political Economy, 70(5), 9-49. https://doi.org/10.1086/258724

Belman, D., \& Heywood, J.S. (1991). Sheepskin effects in the returns to education: An examination of women and minorities. The Review of Economics and Statistics, 73(4), 720-724. https://doi.org/10.2307/2109413

Belman, D., \& Heywood, J.S. (1997). Sheepskin effects by cohort: Implications of job matching in a signaling model. Oxford Economic Papers, 49(4), 623-637. https://doi.org/10.1093/oxfordjournals.oep.a028628

Black, S.E., Devereux, P.J., \& Salvanes, K.G. (2003). Why the apple doesn't fall far: Understanding intergenerational transmission of human capital. American Economic Review, 95(1), 437-449. https://doi.org/10.1257/0002828053828635

Blundell, R., Dearden, L., \& Sianesi, B. (2004). Evaluating the impact of education on earnings in the UK: Models, methods and results from the NCDS. London: Centre for the Economics of Education, London School of Economics and Political Science.

Cellini, S.R., \& Chaudhary, L. (2014). The labor market returns to a for-profit college education. Economics of Education Review, 43, 125-140. https://doi.org/10.1016/j. econedurev.2014.10.001

Desjardins, R., \& Rubenson, K. (2011). OECD Education Working Papers (No. 63). France: Organisation for Economic Co-operation and Development. https://doi. org/10.1787/5kg3nh9h52g5-en 
EPU (Economic Planning Unit) \& World Bank. (2007). Productivity and investment climate survey. Kuala Lumpur: Economic Planning Unit, Prime Minister's Department.

EPU (Economic Planning Unit) \& World Bank. (2012). Malaysia economic monitor. Chapter 3: Modern jobs - Higher wages, secure workers, competitive firms. Kuala Lumpur: Economic Planning Unit, Prime Minister's Department.

Ferrer, A.M., \& Riddell, W.C. (2002). The role of credentials in the Canadian labour market | Le rôle des certificats dans le marché du travail au Canada. Canadian Journal of Economics, 35(4), 879-905. https://doi.org/10.1111/0008-4085.00158

Freeman, R.B. (1977). The overeducated American. New York: Academic Press.

Gibson, J. (2000). Sheepskin effects and the returns to education in New Zealand: Do they differ by ethnic groups? New Zealand Economic Papers, 34(2), 201-220. https://doi.org/10.1080/00779950009544323

Green, F., \& Zhu, Y. (2010). Overqualification, job dissatisfaction, and increasing dispersion in the returns to graduate education. Oxford Economic Papers, 62(4), 740-763. https://doi.org/10.1093/oep/gpq002

Griffin, P., \& Edwards, A.C. (1993). Rates of return to education in Brazil: Do labor market conditions matter? Economics of Education Review, 12(3), 245-256. https://doi. org/10.1016/0272-7757(93)90007-4

Groot, W., \& Oosterbeek, H. (1994). Earnings effects of different components of schooling; human capital versus screening. The Review of Economics and Statistics, 76(2), 317-321. https://doi.org/10.2307/2109885

Hanushek, E. (2013). Economic growth in developing countries: The role of human capital. Economics of Education Review, 37, 204-212. https://doi.org/10.1016/j. econedurev.2013.04.005

Harmon, C., Oosterbeek, H., \& Walker, I. (2003). The returns to education: Microeconomics. Journal of Economic Surveys, 17(2), 115-156. https://doi.org/10.1111/14676419.00191

Heckman, J., Layne-Farrar, A., \& Todd, P. (1996). Human capital pricing equations with an application to estimating the effect of schooling quality on earnings. The Review of Economics and Statistics, 562-610. https://doi.org/10.2307/2109948

Heywood, J.S. (1994). How widespread are sheepskin returns to education in the U.S.? Economics of Education Review, 13(3), 227-234. https://doi.org/10.1016/02727757(94)90010-8

Huber, P.J. (1992). Robust estimation of a location parameter. The Annals of Mathematical Statistics, 35(1), 73-101. https://doi.org/10.1214/aoms/1177703732

Hung, C.Y. (2008). Overeducation and undereducation in Taiwan. Journal of Asian Economics, 19(2), 125-137. https://doi.org/10.1016/j.asieco.2008.02.001

Hungerford, T., \& Solon, G. (1987). Sheepskin effects in the returns to education. The Review of Economics and Statistics, 69(1), 175-177. https://doi.org/10.2307/1937919

Jaeger, D.A., \& Page, M.E. (1996). Degrees matter: New evidence on sheepskin effects in the returns to education. The Review of Economics and Statistics, 78(4), 733-740. https://doi.org/10.2307/2109960

Jepsen, C., Troske, K., \& Coomes, P. (2014). The labor-market returns to community college degrees, diplomas, and certificates. Journal of Labor Economics, 32(1), 95-121. https://doi.org/10.1086/671809 
Katz, L.F., \& Murphy, K.M. (1992). Changes in relative wages, 1963-1987: Supply and demand factors. The Quarterly Journal of Economics, 107(1), 35-78. https://doi. org/10.2307/2118323

Kenayathulla, H.B. (2013). Higher levels of education for higher private returns: New evidence from Malaysia. International Journal of Educational Development, 33(4), 380-393. https://doi.org/10.1016/j.ijedudev.2012.05.008

Kiker, B.F., Santos, M.C., \& De Oliveira, M.M. (1997). Overeducation and undereducation: Evidence for Portugal. Economics of Education Review, 16(2), 111-125. https://doi.org/10.1016/S0272-7757(96)00040-4

Lamo, A., \& Messina, J. (2010). Formal education, mismatch and wages after transition: Assessing the impact of unobserved heterogeneity using matching estimators. Economics of Education Review, 29(6), 1086-1099. https://doi.org/10.1016/j. econedurev.2010.06.002

Liu, V.Y.T., Belfield, C.R., \& Trimble, M.J. (2015). The medium-term labor market returns to community college awards: Evidence from North Carolina. Economics of Education Review, 44, 42-55. https://doi.org/10.1016/j.econedurev.2014.10.009

Mincer, J. (1974). Schooling, experience, and earnings. Human behavior \& social institutions. New York: Columbia University Press. https://doi.org/10.1086/260293

Mincer, J., \& Polachek, S. (1974). Family investments in human capital: Earnings of women. Journal of Political Economy, 82(2), 397-431.

MOHE (Ministry of Higher Education). (2010). Statistics of Malaysian higher learning 2010. Kuala Lumpur: Ministry of Higher Education.

Mora, J.J. (2003). Sheepskin effects and screening in Colombia. Colombian Economic Journal, 1(1), 95-108.

Mora, J.J., \& Muro, J.(2008). Sheepskin effects by cohorts in Colombia.International Journal of Manpower, 29(2), 111-121. https://doi.org/10.1108/01437720810872686

Murillo, I.P., Rahona-López, M., \& Salinas-Jiménez, M. del M. (2012). Effects of educational mismatch on private returns to education: An analysis of the Spanish case (1995-2006). Journal of Policy Modeling, 34(5), 646-659. https://doi. org/10.1016/j.jpolmod.2011.07.012

Park, J.H. (1999). Estimation of sheepskin effects using the old and the new measures of educational attainment in the Current Population Survey. Economics Letters, 62(2), 237-240. https://doi.org/10.1016/S0165-1765(98)00226-2

Patrinos, H.A. (1996). Non-linearities in the returns to education: Sheepskin effects or threshold levels of human capital? Applied Economics Letters, 3(3), 171-173. https://doi.org/10.1080/135048596356609

Pons, E., \& Blanco, J.M. (2005). Sheepskin effects in the Spanish labour market: A public-private sector analysis. Education Economics, 13(3), 331-347. https://doi. org/10.1080/09645290500073852

Psacharopoulos, G., \& Layard, R. (1979). Human capital and earnings: British evidence and a critique. The Review of Economic Studies, 46(3), 485-503. https://doi.org/ $10.2307 / 2297015$

Psacharopoulos, G., \& Patrinos, H.A. (2004). Returns to investment in education: A further update. Education Economics, 12(2), 111-134. https://doi.org/ $10.1080 / 0964529042000239140$ 
Quintini, G. (2011). Right for the job: Over-qualified or under-skilled? OECD Social, Employment and Migration Working Papers (No. 120). https://doi.org/ $10.1787 / 5 \mathrm{~kg} 59 \mathrm{fcz} 3 \mathrm{tkd}-\mathrm{en}$

Riddell, C.W. (2008). Understanding "sheepskin effects" in the returns to education: The role of cognitive skills. Canada: University of Toronto.

Schultz, T.W. (1961). Investment in human capital. The American Economic Review, 51(1), 1-17.

Silles, M.A. (2007). Adult education and earnings: Evidence from Britain. Bulletin of Economic Research, 59(4), 313-326. https://doi.org/10.1111/j.0307-3378. 2007.00268.x

Spence, M. (1973). Job market signaling. The Quarterly Journal of Economics, 87(3), 355-374. https://doi.org/10.2307/1882010

Teixeira, P.N. (2007). Great expectations, mixed results and resilient beliefs: The troubles of empirical research in economic controversies. Journal of Economic Methodology, 14(3), 291-309. https://doi.org/10.1080/13501780701562468

Thrane, C. (2010). Education and earnings in the tourism industry: The role of sheepskin effects. Tourism Economics, 16(3), 549-563. https://doi.org/ $10.5367 / 000000010792278284$

Verhaest, D., \& Omey, E. (2006). Discriminating between alternative measures of over-education. Applied Economics, 38(18), 2113-2120. https://doi.org/ 10.1080/00036840500427387

Weiss, A. (1995). Human capital vs. signalling explanations of wages. The Journal of Economic Perspectives, 9(4), 133-154. https://doi.org/10.1257/jep.9.4.133

$\mathrm{Xu}, \mathrm{D} .$, \& Trimble, M. (2016). What about certificates? Evidence on the labor market returns to nondegree community college awards in two states. Educational Evaluation and Policy Analysis, 38(2), 272-292. https://doi.org/10.3102/0162373715617827

Yunus, N.M. (2014). Factors affecting labour productivity, skilled labour and returns to education in Malaysia. Serdang: Universiti Putra Malaysia.

Yunus, N.M. (2017). Education and earnings in the Malaysian information, communication, and technology sector: The role of certificates of qualification. Australian Journal of Accounting, Economics and Finance, 3(1), 37-50.

Yunus, N.M., \& Hamid, F.S. (2016). The effects of over-education on returns in the graduate labour market. In The European Proceedings of Social and Behavioural Sciences (pp. 384-403). United Kingdom: Future Academy. https://doi.org/10.15405/ epsbs.2016.11.02.35

Yunus, N.M., \& Said, R. (2016). Do higher levels of qualification lead to higher returns to education: Evidence from Malaysian education sector. International Journal of Economics and Financial Issues, 6(6S), 20-26. 